\title{
Kafédialog skaper \\ variasjon i \\ undervisningen og \\ fremmer engasjement
}

En godt organisert kafédialog engasjerer og aktiviserer.

Studentene lærer gjennom samarbeid, deltakelse og

lytting.

\section{Ingjerd Hvatum}

Førstelektor

Fakultet for helsefag, VID vitenskapelige høgskole

\section{Randi Synnøve Tjernæs}

Høgskolelektor

Fakultet for teologi, diakoni og ledelsesfag og Fakultet for sosialfag, VID vitenskapelige

høgskole

\section{Hilde Egge}

Førstelektor og studieleder

Fakultet for helsefag, VID vitenskapelige høgskole

Primærhelsetjeneste

Pedagogikk

Dialog

Kvalitetsforbedring

Verdier

Sykepleien 2021109 (86217) (e-86217)

DOI: 10.4220/Sykepleiens.2021.86217

\section{Hovedbudskap}


Kafédialog er et studentaktivt læringsverktøy for samtaler om livssyn, verdier og relasjoner i profesjonell praksis, men også om følelser, endringsarbeid og ulike typer dilemmaer. Metoden kan bidra til å sikre og forbedre det helsefremmende og forebyggende arbeidet i mange faglige sammenhenger. Ifølge studentene selv kan kafédialog også fungere godt som et profesjonsaktivt læringsverktøy som kan bidra til å heve kompetansen til profesjonsutøvere ute i kommunene. For at metoden skal gi et godt læringsutbytte, bør studentene ha forkunnskaper om temaene som er planlagt for kafédialogen. Det må være relativt få spørsmål på menyen, tidsbruken må planlegges godt, og man må unngå for mange gjentatte oppsummeringer.

Ifølge Sylte (1) oppnår studentene læringsutbytter i ulike emner mest effektivt gjennom studentaktive læringsformer og evalueringsformer som i større grad fremmer læring gjennom egenaktivitet. Læring skjer best når studentene er aktive, og når de opplever lærestoffet som viktig og meningsfullt (1).

Det å lære i samarbeid med andre er både en velegnet og en mye benyttet metode. Ønskes det for eksempel refleksjon rundt et tema, kan forelesning være mindre egnet enn en studentaktiv metode (2).

Rynning (3) fremhever student-student-relasjonen og stiller spørsmålet om studenter lærer mer hvis man forteller dem mindre, ved at de dermed selv blir mer aktive. Det kan bety at man i st $\varnothing$ rre grad bør benytte andre metoder enn tradisjonelle forelesninger.

\section{Kafédialog skaper engasjement for læring}

Kafédialog tar utgangspunkt i to sentrale teoretiske uttrykk: dialog og kafé. I dialogen kreves det en evne til å lytte, være empatisk og være åpen for andres argumenter samt en evne til å endre standpunkt. Læring oppnås gjennom samarbeid, deltakelse og lytting.

Valget av kafeen som møteplass er basert på ideen om at en uformell ramme rundt refleksjon og dialog $i$ mindre grupper bidrar til gjensidig forståelse og kunnskapsutvikling $(4,5)$. 


\section{Kafédialog}

En kafédialog består av et oppsett av småbord, og oppdekning av bordene med kaffe/te/vann og kjeks som deltakerne kan forsyne seg med. Post-it-lapper og penner deles ut sammen med en meny som inneholder problemstillingene som dialogen skal ta utgangspunkt i.

Lederen av kafédialogen kalles hovmester og organiserer bordskiftene. Ved hvert bord velges det ut en kafévert som har i oppgave å ønske velkommen, lese menyen og gi alle en-to minutter til å tenke gjennom problemstillingen. Deretter får alle komme med innspill etter tur, før ordet er fritt.

Kaféverten oppsummerer kort det som er blitt sagt når neste gruppe kommer, og til slutt er det oppsummering av hovmesteren i plenum. På den måten blir det både individuell refleksjon, grupperefleksjon og til slutt en plenumsrefleksjon.

Ifølge Elvekrok og Smith (6) førte kafédialog til økt problemforståelse og $\varnothing \mathrm{kt}$ engasjement hos studentene som deltok. Studentene opplevde at det $\varnothing \mathrm{kte}$ engasjementet vedvarte i forelesningene som ble gjennomført etter kafédialogen. Metoden skapte positivt engasjement blant sykepleiere som tok doktorgrad innen ledelse og politikk. En forutsetning var at deltakerne hadde forkunnskaper om temaene kafédialogen handlet om (4).

\section{Hensikt og gjennomføring}

Vi ønsket å unders $\varnothing$ ke om kafédialog kan egne seg som et bidrag til å oppnå læringsutbyttene i studiets profilemne, Livssyn, verdier og relasjoner i profesjonell praksis. Vi etterspurte derfor studentenes erfaringer med verktøyet knyttet til temaene i dette emnet, både personlig og i møte med sine brukere.

\section{Profilemner}


Et profilemne er et emne som er utviklet særskilt for den enkelte høyskolen. De fleste høyskoler har egne profilemner. På Vid er det et profilemne på både bachelor- og masternivå, som er obligatorisk for alle studenter. Profilemnet på masternivå, Livssyn, verdier og relasjoner i profesjonell praksis, tar særlig for seg profesjonell praksis og vektlegger blant annet en verdibevisst forståelse av hva VIDs diakonale verdier handler om.

Emnet tar opp utfordringer knyttet til maktproblematikk og til livssynsmessig og verdimessig pluralisme i profesjonell praksis. Studentene skal opparbeide seg en forståelse av hva eget verdi- og livssynsmessig ståsted betyr i møte med brukere med ulike verdier og livssyn.

Vi fulgte Elvekrok og Smiths mal for den pedagogiske utformingen av kafédialog (6). Spørsmålene som dannet utgangspunkt for dialogen, ble laget på bakgrunn av undervisning i profilemnet.

Spørsmålene omhandlet tenkte situasjoner hvor livssynsspørsmål er aktuelle: Hvordan kan vi skape åpenhet om livssynsspørsmål? Hvilke verdier styrer prioriteringer på arbeidsplassen? Hva kan være utfordringer ved religiøst mangfold på arbeidsplassen? Hvilken rolle spiller emosjonell intelligens og affektiv kompetanse? Hva former våre verdier, og hvordan vurderer vi våre egne verdier i møte med andres verdier? Hvordan blir våre handlinger påvirket av våre verdier, og hvilke verdier frykter vi skal bli utfordret i vår profesjonelle praksis?

Studentene reflekterte over spørsmålene både individuelt, i gruppe og i plenum.

\section{Metode}

Vår studie har et kvalitativt design med åpne spørsmål på et evalueringsskjema som datainnsamlingsmetode. Skjemaet hadde sju spørsmål, og har stor likhet med evalueringsskjemaet brukt i Elvekrok og Smiths studie (6). Førtifem studenter fylte ut skjemaet. 
Studentene ble spurt om hva de syntes om kafédialog som undervisningsform, og om hva de likte og mislikte. Videre ble det spurt om metoden tilførte ny kunnskap og bevissthet om temaene i profilemnet, og om metoden kunne brukes i helsesykepleiertjenesten og i tilfelle i hvilke profilemnetemaer.

Kvalitativ innholdsanalyse inspirert av Graneheim og Lundman (7) ble anvendt for å identifisere likheter og forskjeller i tekstmaterialet. Tekstene ble lest flere ganger for å få en opplevelse av helheten.

Deretter ble meningsbærende enheter identifisert $\mathrm{i}$ tekstmaterialet, kondensert og kodet. Koder med tilsvarende innhold ble satt sammen til subkategorier og en hovedkategori. Et eksempel på analyse av innsamlet data er vist i tabell 1.

Tabell 1. Eksempel på analyseprosess av innsamlet data

\begin{tabular}{|c|c|c|c|c|}
\hline Meningsenhet & Kondensert meningsenhet & Kode & Subkategori & Hovedkategori \\
\hline $\begin{array}{l}\text { Godt å sitte rundt et bord og } \\
\text { snakke, fint å ikke bare se nakken } \\
\text { til den andre }\end{array}$ & $\begin{array}{l}\text { Snakke sammen rundt et } \\
\text { bord ansikt til ansikt }\end{array}$ & Sosialt & \multirow{3}{*}{$\begin{array}{l}\text { Engasjerende } \\
\text { lærings- } \\
\text { fellesskap }\end{array}$} & \multirow{5}{*}{ Læringspotensia } \\
\hline $\begin{array}{c}\text { Fikk en boost til å lære mer } \\
\text { om emnene da jeg fikk en } \\
\text { dypere innsikt }\end{array}$ & Boost til å lære & & & \\
\hline $\begin{array}{l}\text { Det at det ble variasjon } \\
\text { i undervisningen }\end{array}$ & Variasjon i undervisningen & & & \\
\hline $\begin{array}{l}\text { Flott med refleksjoner, men er } \\
\text { det fag? Det krever at studentene } \\
\text { har lest, har tilegnet seg kunnskap }\end{array}$ & Krever forkunnskaper & $\begin{array}{l}\text { Forberedelse } \\
\text { på temaet }\end{array}$ & \multirow{2}{*}{$\begin{array}{l}\text { Planlegging/ } \\
\text { organisering }\end{array}$} & \\
\hline Litt for lange (avanserte) spørsmål & $\begin{array}{l}\text { Krevende drøftinger } \\
\text { på kort tid }\end{array}$ & $\begin{array}{l}\text { Færre retter } \\
\text { på menyen }\end{array}$ & & \\
\hline
\end{tabular}

\section{Etiske hensyn}

Det ble opplyst om at det var frivillig å besvare evalueringsskjemaet. Studentene ble imidlertid oppfordret til å evaluere om denne pedagogiske metoden var velegnet for læring i profilemnet. Besvarelsen var anonym. 


\section{Resultater}

I analyseprosessen endte vi opp med en hovedkategori og fire subkategorier. Hovedkategorien var læringspotensial, og subkategoriene var engasjerende læringsfellesskap, planlegging og organisering, egnede temaer og nytteverdi for egen profesjonsut $\varnothing$ velse (se figur 1).

Figur 1. Hovedkategori og subkategorier

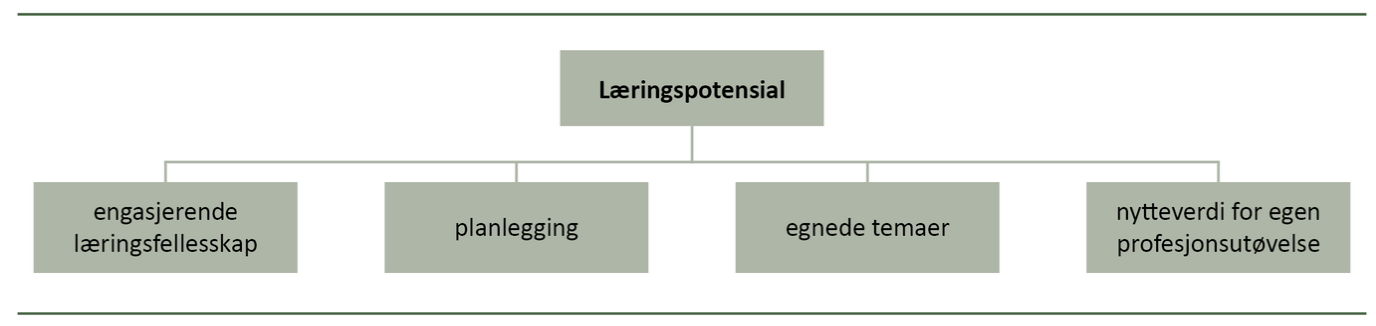

\section{Engasjerende læringsfellesskap}

På spørsmålet om hva studentene syntes om kafédialog som undervisningsform, uttrykte flere at variasjon i undervisningen fremmet engasjement, og at det ble lettere å lære når man snakket sammen i mindre grupper. Det fordret imidlertid god styring av kaféverten - her var det læreren - slik at alle fikk bidra med sine synspunkter.

\section{«Det var stimulerende å diskutere viktige temaer som ikke nødvendigvis har et fasitsvar.»}

Å bli presentert for ulike perspektiver på et tema kan bidra til st $\varnothing$ rre åpenhet for andres syn. Studentene sa at de gjennom kafédialogen lærte mer og fikk en dypere innsikt, og at metoden var velegnet for temaene i profilemnet. En student sa:

«Jeg lærte mye ved å høre refleksjon fra flere, og det ga en boost til å få dypere innsikt. Det var en hjelp til å forstå store, komplekse temaer.» 
På spørsmålet om hva de likte godt med kafédialog, fremhevet studentene at det var en fin måte å bli kjent med flere i klassen på, få nye perspektiver og høre andre studenters tanker enn tankene til dem de vanligvis var sammen med. Det var stimulerende å diskutere viktige temaer som ikke nødvendigvis har et fasitsvar.

\section{Planlegging og organisering}

Det kom frem av evalueringen at det ble for lite tid til samtalen, og at dialogen kunne vært disponert annerledes; det var for mange og lange spørsmål med krevende drøftinger, mange gjentakelser i oppsummeringen til slutt og litt ensformig for kaféverten, som gikk glipp av andre temaer enn sitt eget.

For at kafédialogen skulle gi læringsutbytte, var det viktig at spørsmålene baserte seg på tidligere undervisning og litteratur, og at studentene møtte med forkunnskaper om temaene som skulle tas opp. En student sa:

«Flott med refleksjoner, men er det fag? Det krever at studentene har lest og har tilegnet seg kunnskap.»

\section{Egnede temaer}

Kafédialogen ga studentene ny kunnskap og bevissthet om temaene i profilemnet ved at flere slapp til med sine tanker når det var mindre grupper. Det ble en dynamisk læring ved at samtalen bygget videre på tidligere innspill og refleksjoner. En student sa:

«Jeg har fătt høre andres tanker og refleksjoner og blitt mer bevisst på mangfoldet og kompleksiteten rundt verdier og livssyn og hvor mye det påvirker oss som yrkesutøvere.»

\section{«Noen syntes refleksjonen tok mye av den tiden som ellers kunne vært brukt til faglig innhold.»}


Enkelte stilte spørsmål ved om temaene det ble reflektert over, var relevante for det faglige innholdet $\mathrm{i}$ helsesykepleierutdanningen. Noen syntes refleksjonen tok mye av den tiden som ellers kunne vært brukt til faglig innhold.

Studentene mente det var viktig at temaene ble relatert til utøvelsen som helsesykepleier. Alternative temaer som ble foreslått, var følelser, endringsarbeid og ulike typer dilemmaer.

\section{Nytteverdi for egen profesjonsutøvelse}

Studentene så verdien av kafédialog, og de ble inspirert til å bruke dette verktøyet $\mathrm{i}$ andre sammenhenger. Relevante kontekster er der hvor mennesker trenger å utvikle felles forståelse for en kompleks tematikk, samt for ulike typer sensitiv og følelsesladet tematikk hvor refleksjon er nødvendig.

Dette kunne være i ulike sammenhenger som kollegamøter, tverrfaglig eller tverrkommunalt samarbeid og fagdager eller i møte med ulike brukergrupper - barn, unge og foreldre - i etterkant av undervisning. En student sa:

«Kan være aktuelt verktøy både blant kollegaer og skolebarn.»

Eksempler på vanskelige og sensitive temaer i yrkesutøvelsen som studentene foreslo, var etikk, seksualitet, prevensjon, identitet, mobbing, nettvett, skilsmisse, $\mathrm{d} \varnothing \mathrm{d}$, vold i nære relasjoner samt eksistensielle temaer og ulike livssynsspørsmål. De mente at metoden ville egne seg spesielt godt for ulike dilemmaer der det ikke finnes noen fasit.

\section{Diskusjon}

\section{Engasjerende læringsfellesskap}

Studentene uttrykte at de ble engasjert av å sitte i mindre grupper. Dette samsvarer med teorier som sier at det å lære i samarbeid med andre egner seg godt for læring $(1,2)$, og studien til Dawkins og Salomon (4), som viste at samarbeid med andre skaper engasjement. 
Studentene fremhevet imidlertid at det var en forutsetning for å bli engasjert at kaféverten var nøye med at alle fikk bidra. Dette samsvarer med Rynning (3), som fremhever at student-student-relasjonen er en viktig faktor for læring.

I likhet med Strøms $\varnothing$ og medarbeidere (2), som hevder at studentaktive metoder er mer egnet ved refleksjon, beskrev studentene at de fikk en dypere innsikt i og hjelp til å forstå komplekse temaer og skape større åpenhet om andres synspunkter, i tråd med læringsutbyttet. Dette samsvarer med erfaringene knyttet til metoden fra verdibasert ledelse (6).

\section{Planlegging og organisering}

Som nevnt mente studentene at dersom kafédialogen skulle gi faglig utbytte, var det nødvendig med forkunnskaper. Dette er i tråd med studentenes oppfatning i Elvekrok og Smiths studie (6), som mente at det var nødvendig med et visst kunnskapsnivå for å kunne samtale om komplekse problemstillinger, og at problemstillingene derfor må ta utgangspunkt i hva studentene tidligere har lært.

Strøms $\varnothing$ og medarbeidere (2) hevder at forelesning kan være mindre egnet enn studentaktive metoder når det $\varnothing$ nskes refleksjon rundt et emne. Ifølge studentene forutsetter det at temaene knyttes til relevant faglig innhold i utdanningen. En utfordring kan være at studentenes nivå er ulikt, og det kan bli kjedelig for dem som allerede har tilegnet seg læringsutbyttet (2).

\section{«Et forslag kan være å begrense menyen til én case med ulike dilemmaer.»}

Studentene mente at de fikk for knapp tid til å samtale i forhold til problemstillingenes omfang. Dette kan stå i kontrast til flere av studentene i studien til Elvekrok og Smith, som nettopp påpekte at den gode tiden tvang dem til å gå mer i dybden på temaet (6). Et forslag kan være å begrense menyen til én case med ulike dilemmaer. 
For å forhindre for mange gjentakelser $\mathrm{i}$

oppsummeringen og få en mer effektiv utnyttelse av

metoden kunne studentene også fått en skriftlig redegjørelse for metoden dagen før med avklarte roller. Kafévertene kunne dermed fått forberedt seg på sin oppgave som prosessleder og den som skal holde tråden.

Noen videre utfordringer ved kafédialog som læringsmetode er at den krever fysisk god plass, tid, god forberedelse knyttet til menyvalg og av kaféverter, og trygg ledelse av hovmesteren.

\section{Egnede temaer}

Studentene stilte spørsmål ved om temaene det ble reflektert over, var relevante for det faglige innholdet $\mathrm{i}$ helsesykepleierutdanningen. Ifølge Sylte (1) er det viktig at lærestoffet oppleves som meningsfylt for studenten for å oppnå læring.

For studentene var det viktig at kafémenyen, altså temaene de skulle snakke om, ble relatert til verdivalg som er aktuelle for utøvelsen av helsesykepleieryrket og andre situasjoner som involverer følelser, som for eksempel ulike typer endringsarbeid, da forforståelsen av trosspørsmål og verdiladede spørsmål kan variere blant studentene (8).

Imidlertid mente andre studenter at menyene bidro til ny kunnskap og bevissthet omkring verdier og livssyn og hvor mye det påvirker oss som yrkesutøvere.

\section{Nytteverdi for egen profesjonsutøvelse}

Kafédialog som metode åpner for samtaler studentene imellom om verdier, normer, følelser, affekter og livssyn, temaer som kan knyttes til utvikling av dømmekraft. Dømmekraft og refleksjon er dynamiske egenskaper, og de kan utvikles gjennom hele livet (9). 
Dømmekraft er blant annet summen av vår faglige kunnskap, etikk, samvittighet, våre livsverdier, vår forstand, vår intuisjon, vår kompetanse og vår samlede livserfaring. Disse elementene står i et samspill med hverandre (10).

Dømmekraft er sentralt i utdanningen av helsesykepleiere. Etter vår erfaring vil kafédialog kunne utvikle dømmekraft fordi metoden innebærer refleksjon over de ulike problemstillingene som ble presentert.

Ifølge forskrift om nasjonal retningslinje for helsesykepleierutdanningen (11) skal helsesykepleiere jobbe forebyggende og helsefremmende med barn, unge og familier innenfor en rekke ulike områder hvor det ikke finnes fasitsvar på hvordan man skal gå frem, men hvor utfallet kan avhenge av tilnærmingen. Som eksempler på temaer hvor det kunne være nyttig å bryne sine egne verktøy og fremgangsmåter mot kollegaer og andre samarbeidende profesjoner, nevnte studentene blant annet seksuell helse, foreldrerollen, mobbing, nettvett, skilsmisse og $\mathrm{d} \varnothing \mathrm{d}$.

\section{«Kafédialog kan være en god alternativ pedagogikk når ulike grupper skal $\emptyset$ ke sin kompetanse på temaer som er komplekse og uten fasitsvar.»}

Innledningsvis i denne artikkelen nevnes studentaktiv læring i form av diskusjon, refleksjon og kreativ tenkning (1) som den mest effektive måten å lære på, samtidig som det henvises til Von Krogh og medarbeidere (12), som vektlegger betydningen av å legge til rette for at ny kunnskap kan skapes på arbeidsplassene. I tråd med dette kan kafédialog lanseres som en profesjonsaktiv læringsmetode for videreutvikling/kompetanseheving av helsesykepleiere innen sitt fagfelt på egen arbeidsplass.

I tillegg til kollegiale og tverrfaglige samlinger som egnede kontekster for kafédialog nevner også studentene at kafédialog kan egne seg for grupper med barn, unge og familier i etterkant av undervisning. 
Som alternativ til at deltakerne selv er kaféverter i brukergrupper, kan helsesykepleierkollegaer eller lærere i skolehelsetjenesten ta den rollen. God informasjon om metoden, god tid i forkant, kan være avgjørende for resultatet.

Men forutsatt at planleggingen er god, kan kafédialog være en god alternativ pedagogikk når ulike grupper skal øke sin kompetanse på temaer som er komplekse og uten fasitsvar, og hvor $\varnothing \mathrm{kt}$ d $\varnothing \mathrm{mmekraft}$ og forståelse for den andre er en sentral del av målet.

\section{Metodekritikk}

I evalueringen stilte vi spørsmålet «Hva likte du ved metoden Kafedialog?». Imidlertid stilte vi ikke et likelydende spørsmål «Hva mislikte du ved metoden Kafedialog?». I stedet spurte vi: «Var det noe du mislikte?» Det kan ha ført til at vi fremhevet den positive siden og tonet ned den negative siden ved metoden i vår evaluering. Likeledes kunne et dybdeintervju ha gitt mer informasjon enn et spørreskjema.

\section{Konklusjon}

Studiens hensikt var å unders $\varnothing$ ke om kafédialog er et egnet verktøy for undervisning i temaer som livssyn, verdier og relasjoner i profesjonell praksis for helsesykepleierstudenter. På bakgrunn av studiens resultater kan vi hevde at det er et læringspotensial i å bruke dette verktøyet til å snakke om slike temaer dersom temaene knyttes til helsesykepleieres profesjon, studentene har med seg forkunnskaper om temaene inn i dialogen, dersom det er få spørsmål på menyen, man planlegger tidsbruken godt, og man unngår for mange gjentatte oppsummeringer.

En godt organisert kafédialog vekker engasjement for læring og bidrar til utvikling av dømmekraft. Ifølge studentene kan bruksområdet for verktøyet utvides til samtaler om følelser, endringsarbeid og ulike typer dilemmaer. 
Ut fra sine erfaringer med å delta i kafédialog så studentene at det kan være et nyttig verktøy å ta med seg ut $\mathrm{i}$ arbeidslivet, hvor mange vanskelige og verdiladede temaer må behandles. Bruk av kafédialog kan bidra til kvalitetssikring og kvalitetsforbedring av det forebyggende og helsefremmende arbeidet, og egne seg i mange ulike faglige sammenhenger som tverrfaglige møter, overfor ulike brukergruppe og på fagdager.

På samme måte som kafédialog kan inngå som et studentaktivt læringsverktøy, kan det også ifølge studentene fungere godt som et profesjonsaktivt læringsverktøy. Dette er så langt et uutforsket område, men kan være utgangspunkt for en oppfølgingsstudie.

\section{Referanser}

1. Sylte AL. Profesjonspedagogikk. Profesjonsretting/yrkesretting av pedagogikk og didaktikk. Oslo: Gyldendal Akademisk; 2016.

2. Strøms $\varnothing$ HI, Lycke KH, Lauvås P. Når læring er det viktigste: undervisning i høyere utdanning. 2. utg. Oslo: Cappelen Damm Akademisk; 2016.

3. $\quad$ Rynning M. Kan våre studenter lære mer hvis vi forteller dem mindre? Uniped. 2014;37(3):49-62.

4. Dawkins V, Solomon A. Introducing the world café to Doctor of Nursing practice students. J Nurs Educ. 2017;56(10):638-9.

5. Brown J, Isaacs D. The World Cafe: shaping our futures through conversations that matter. San Francisco: Berrett-Koehler Publishers; 2005.

6. Elvekrok I, Smith KH. Kafédialog som pedagogisk verkt $\varnothing$ y. Uniped. 2013;2(36):25-37.

7. Graneheim UH, Lundman B. Qualitative content analysis in nursing research: concepts, procedures and measures to achieve trustworthiness. Nurse Educ Today. 2004;24(2):105-12. 
8. Leenderts TA. Person og profesjon. Om menneskesyn og livsverdier i offentlig omsorg. Oslo: Gyldendal Akademisk; 2014.

9. Nygaard MR. Diakoners profesjonsvilkår i Den norske kirke. Tidsskrift for praktisk teologi. 2011;28(2):32-46.

10. Christoffersen SA. Profesjonsetikk. Om etiske perspektiver i arbeid med mennesker. Oslo: Universitetsforlaget; 2011.

11. Forskrift 9. april $2021 \mathrm{nr} .1146$ om nasjonal retningslinje for helsesykepleierutdanningen. Tilgjengelig fra: https://lovdata.no/dokument/SF/forskrift/2021-04-091146 (nedlastet 13.09.2021).

12. Von Krogh G, Kazuo I, Ikujiro N. Slik skapes kunnskap. Hvordan frigjøre taus kunnskap og inspirere til nytenkning i organisasjoner. Oslo: NKS-forlaget; 2001. 